\title{
Implication of Future Time Perspective and Hope on the Continuance Commitment of Hotel Employees
}

\author{
Adrie Oktavio ${ }^{*}$, Thomas Stefanus Kaihatu ${ }^{2}$ \\ ${ }_{1,2}$ Universitas Ciputra Surabaya, Indonesia \\ ${ }^{1}$ adrie.oktavio@ciputra.ac.id, ${ }^{2}$ thomas.kaihatu@ciputra.ac.id *corresponding author
}

\begin{abstract}
In the Indonesian hotel industry, high employee turnover rates are very common costly. One of the reasons that causes hotel employee turnover to be high is low commitment. The low commitment is triggered by the low hope of hotel employees to remain and to be committed to continuing their careers in the hotel where they are working today. Employees need certainty about their future that should be guaranteed by hotel management. This study tries to analyze the role of Future Time Perspective (FTP) and its effect on hope and continuance commitment. The data were derived from distributing questionnaires to hotel employees spread in 45 three-star hotels in Surabaya, and subsequently analyzed using the General Structured Component Analysis (GSCA) tool. The results show that FTP influences hope and continuance commitment significantly. Similarly, hope has a significant effect on continuance commitment. Hope is also able to act as a mediator between FTP and continuance commitment.
\end{abstract}

Keywords: hotel industry, future time perspective, hope, continuance commitment

\section{Implikasi Future Time Perspective dan Harapan Terhadap Continuance Commitment Karyawan Hotel}

\begin{abstract}
Abstrak
Di industri perhotelan Indonesia, tingkat turnover karyawan yang tinggi sudah menjadi rahasia umum dan sangat memakan biaya. Salah satu alasan yang menyebabkan tingginya tingkat turnover karyawan hotel adalah komitmen yang rendah. Komitmen yang rendah tersebut dipicu oleh rendahnya tingkat harapan karyawan hotel untuk tetap tinggal serta berkomitmen untuk melanjutkan karir di hotel tempat mereka bekerja saat ini. Karyawan hotel membutuhkan kepastian akan masa depannya yang seharusnya bisa dijamin oleh pihak manajemen hotel. Penelitian ini mencoba menganalisa peran Future Time perspective (FTP) dan pengaruhnya terhadap harapan dan continuance commitment karyawan hotel. Data penelitian berasal dari penyebaran kuesioner kepada karyawan hotel yang tersebar di 45 hotel bintang tiga di Surabaya dan selanjutnya dianalisis menggunakan alat analisis General Structured Component Analysis (GSCA). Hasilnya menunjukkan bahwa FTP mempengaruhi harapan dan continuance commitment secara signifikan. Harapan juga berpengaruh secara signifikan terhadap continuance commitment. Harapan juga berperan sebagai mediator antara FTP dan continuance commitment.
\end{abstract}

Kata kunci: industri perhotelan, future time perspective, harapan, continuance commitment

\section{INTRODUCTION}

Commitment to work certainly must be owned by everyone who works in a company or organization including a hotel (Quinn \& Thakor, 2018) because if employees do not have a commitment to work, then the goals of the company or organization will not be achieved (Hofmann \& Stokburger-Sauer, 2017). However sometimes, a company or organization pays little attention to employee commitment, so this will impact on employee performance or loyalty (Tomic et al., 2018). Organizational commitment is a reflection of how an 
individual already has a level of trust and acceptance, and is bound to organizational goals (Tamer \& Dereli, 2014). Someone committed to the organization means having loyalty to it (Guillon \& Cezanne, 2014). Employees who have a commitment will work optimally, so they can devote their attentions, thoughts, energies and time to their work, so that what they have done is in line with what is expected by the company (Reid \& Ramarajan, 2016).

One dimension of organizational commitments is continuance commitment (Meyer $\&$ Allen, 1991). Continuance commitment refers to the desire of employees to remain in the organization because of the calculation or analysis of profits and losses in which the perceived economic value of surviving in an organization is compared to leaving the organization. The longer employees stay with their organization, the more they are afraid of losing what they have invested in the organization so far (Meyer \& Allen, 1991). Overall, continuance commitment is considered having unfavorable results on attitudes and behaviors compared to affective commitment and normative commitment (Meyer et al., 2002). This is not surprising because in some cases continuance commitment is usually defined as a unidimensional construct when the evidence has suggested otherwise as in Ko et al. (1997). Fortunately, many subsequent studies have established continuance commitment as a multidimensional construct such as Bentein et al. (2005) and Stinglhamber et al. (2002). Both studies adapted the factor analysis of McGee \& Ford (1987) study using Meyer \& Allen (1984) continuance scale, which found that continuance commitment includes two dimensions. The first dimension involves commitment due to the lack of alternative job opportunities, while the second one concerns the sacrifice felt when leaving the organization.

As explained earlier, employees who have high continuance commitment are influenced by an analysis of profit and loss calculations where the perceived economic value of surviving in an organization is compared to leaving the organization. One of them concerns employee perspectives on the certainty of their future in the organization. The more they are convinced to remain in the organization, the more they are convinced of having a bright future regarding their positions or careers in the future. This perspective according to Zimbardo \& Boyd (1999) is called future time perspective (FTP).

FTP is a fundamental component of socioemotional selectivity theory. The theory of socioemotional selectivity shows that individuals are motivated by their time perception. As a change in perspective of one's future time, they will invest energy and resources towards instrumental or emotional results (Carstensen et al., 1999). Zimbardo \& Boyd (1999) also explained that FTP is a factor that can affect life and human nature in many ways in depth. Therefore, as a human nature, FTP can influence various work-related behaviors and attitudes such as organizational commitments which also include continuance commitment (I. J. Park \& Jung, 2015).

The relationship between FTP and continuance commitment may not occur directly but is mediated by psychological capital. Psychological capital is the study and application of the strengths of human resources that are positively oriented, and psychological capacities that can be measured, developed, and managed effectively to improve 
performance in the workplace today (Luthans, 2002). Psychological capital consists of four dimensions, and one of them is hope (Luthans et al., 2008).

Hope is a belief to determine goals to be achieved significantly (Çetin, 2011). Hope is a state of mind that is based on the interactive feeling of two beliefs: personal goals that can be achieved (agency thinking) and path planning that enables the achievement of these goals (Fruiht, 2014; Snyder et al., 1996). Hope is also associated with hard work or persistence to achieve goals (N. Park et al., 2004) and in turn, hope is influenced by features that are biased towards agency planning and thinking (Snyder et al., 1996, 2002). At this point, FTP is very relevant because it is characterized by predictions of the condition of one's future existence and the persistence of achieving goals (Zimbardo \& Boyd, 1999). Hope also implies a belief that efforts will lead to results (Epel et al., 1999). Therefore, agency thinking is directly relevant to the development of hope. If hope is related to achieving goals and can also be based on FTP, there is a possibility that the relationship between FTP and continuance commitment can be measured. However, employee hopes in organizations are vital things that are worth learning, so that they can strengthen the organization. It affirms the best and most promising dimension of social and organizational life, and provides a moral image of the future to guide collective action (Ludema et al., 1997).

This research was conducted in the hotel industry because it has a high turnover rate. It is common knowledge that hotel employee turnover rates in Indonesia are very high and costly (Holston-Okae \& Mushi, 2018). The phenomenon of high employee turnover in the hotel industry has also occurred in many countries and is increasing in number every year, so there is a need of investigation to find the cause of the high turnover (Qiu et al., 2015). One example of the reasons that causes hotel employee turnover rates to be high is low job satisfaction, so that employees also have low commitment and lack of career development which naturally influence employee hopes of future certainty in the organization (Albattat et al., 2014; Zimmerman et al., 2019). Therefore, researchers are interested in examining how high FTP hotel employees have an impact on employees' hope for their future existence and their commitment to stay and continue their careers in hotels where they are working.

\section{METHOD}

This associative causal type research was conducted for 6 months starting in JuneNovember 2019. The population involved in the study included employees of nonmanagerial level of three-star hotels in Surabaya. According to data released by BPS Surabaya (2018) the number of three-star hotels is 45 hotels. Based on these data, researchers distributed research questionnaires to all three-star hotels in which each hotel received 3 questionnaires, so that the total questionnaires distributed were 135 questionnaires. From a number of questionnaires that have been distributed, questionnaires returned and eligible to be processed were 97 questionnaires, so that the response rate was $72 \%$. The data from the dissemination were then processed with General Structured Component Analysis (GSCA) which is an analysis tool in the Structural Equation Modeling (SEM) analysis method. The output of the GSCA is a measure of fit in the measurement 
model (including validity and reliability testings), structural models, and overall models (Hwang et al., 2017).

FTP variables are measured using thirteen indicators adopted from the research of Zimbardo \& Boyd (1999). Variable hope is measured using six indicators adapted from research by Snyder et al. (1996). The last variable is continuance commitment using eight measurement indicators belonged to Allen \& Meyer (1990). All measurement indicators for the three variables use a 7-point Likert scale.

\section{FINDING AND DISCUSSION}

Based on the results of the questionnaire data, it is known that the majority of respondents are male, as many as 59 respondents (61\%), while the remaining 38 respondents $(39 \%)$ are female. From the age factor, 13 respondents (13\%) are less than 25 years old; 37 respondents (38\%) aged between 26-35 years; 28 respondents (29\%) aged between 36-45 years; and the remaining 19 respondents (20\%) aged over 46 years. Furthermore, from the length of service in the current hotel, 39 respondents (40\%) have been employees of the hotel in the current workplace for less than 2 years; 22 respondents (23\%) have worked in the range of $2-4$ years; then 18 respondents (19\%) have worked in the range of 4-6 years; 9 respondents $(9 \%)$ have a working period in the range of 6-8 years; and the remaining 9 respondents (9\%) have worked for more than 8 years. Based on the amount of received income (take home pay), 47 respondents (48\%) earn less than 4 million rupiahs; 33 respondents (34\%) get monthly income in the range of 4-6 million rupiahs; while the remaining 17 respondents $(18 \%)$ earn more than 6 million rupiahs. From the respondents' marital status, it is obtained that 71 respondents (73\%) are married and the remaining 26 respondents $(27 \%)$ are single.

From the results of data processing using GSCA, the results show that all indicators used in collecting data have been declared valid and reliable. Composite Reliability as seen from the value of Cronbach's alpha and Dillon-Goldstein's rho can be used to check the internal consistency of the indicators for each latent variable. Average Variance Extracted (AVE) can be used to check latent variable Convergent Validity. The number of eigenvalues greater than one per block of indicators can be used to check the uni-dimensionality of the indicators. In Table 1, the values of Cronbach's Alpha and Dillon-Goldstein's Rho show numbers above 0.6 , so that all indicators are reliable. Meanwhile, the AVE value is also above 0.6 , so it meets the validity requirements.

Table 1. Convergent Validity and Composite Reliability

\begin{tabular}{cccc}
\hline Variable & Cronbach's alpha & Dillon-Goldstein's rho & AVE \\
\hline FTP & 0.9701 & 0.9735 & 0.7395 \\
Hope & 0.9343 & 0.9485 & 0.7552 \\
Continuance & 0.9076 & 0.9255 & 0.6096 \\
Commitment & & & \\
\hline
\end{tabular}

From the Fit model test results in Table 2, it can be seen the known FIT value of 0.6544, Adjusted FIT (AFIT) of 0.6467, Goodness-of-Fit Index (GFI) of 0.9984, and 
Standardized Root Mean Square Residual (SRMR) of 0.0691. The FIT value (ranging from 0 to 1 ) explains the total variance of all variables that can be explained by a particular model (Hwang et al., 2017). FIT value of 0.6544 means that the research model is good enough to explain the studied phenomenon. The object of the study is able to influence the continuance commitment variable by $65.44 \%$, and the remaining $34.56 \%$ is explained by other variables outside the model.

Table 2. Identification of Goodness of FIT

\begin{tabular}{cc}
\hline \multicolumn{2}{c}{ Fit Model } \\
\hline FIT & 0.6544 \\
AFIT & 0.6467 \\
GFI & 0.9984 \\
SRMR & 0.0691 \\
\hline
\end{tabular}

For Adjusted FIT (AFIT), it shows a lower value than FIT because AFIT measures a more complex model while FIT is very sensitive to the complexity of the model. For that reason, the AFIT value is better used in interpreting the accuracy of the model and as a basis for comparing models. This is because the variables that affect continuance commitment are not just one, but two variables. AFIT value of 0.6467 means that the diversity of FTP, hope, and continuance commitment variables is $64.67 \%$, while the remaining $35.33 \%$ is explained by other variables outside this research model.

The GFI value indicates the level of relevance between the facts studied and the theories used in the research, described by the conceptual model of the study. The conceptual model is stated to be able to explain the level of strong relevance if the GFI value passes the fit criteria, and if the value exceeds $90 \%$. The GFI test results of this study show a value of 0.9984 or around $99.84 \%$, which means the model formed is acceptable and shows a strong relevance between the theory and the phenomenon of research. SRMR values indicate the level of model fit. SRMR value which is getting smaller and approaching 0 indicates a better model. SRMR value in this study is 0.0691 , so it can be stated that the model formed in the study is good enough.

The Estimate of Loading value presented in Table 3 shows the influence of 13 indicators on the formation of FTP variables, 6 indicators on the hope variables, and 8 indicators on the continuance commitment variables. From the FTP variables, it is known that the FTP1 indicator "I make lists of things to do" has the highest estimate of loading value of 0.9645 , so that the indicator is the most likely to be able to explain and represent the FTP variables, so it is important to maintain. In the hope variables, the highest estimate of loading is in the Hope 3 indicator "There are lots of ways around any problem that I am facing now" which is 0.9413 , so that it is most able to explain the hope and important variables to be maintained. For the continuance commitment variable, an important indicator to maintain because it most represents the continuance commitment variable is the CC7 indicator "One of the few serious consequences of leaving this organization would be the scarcity of available alternatives" with an estimated value of loading of 0.8966 . 
Jurnal Economia, 16(2), October 2020, 161-172

Table 3. Output Conformity of Variable Measurement Models

\begin{tabular}{|c|c|c|c|c|c|}
\hline Variables & Indicators & $\begin{array}{c}\text { Estimate of } \\
\text { Loading }\end{array}$ & $\begin{array}{c}\text { Standard } \\
\text { Error }\end{array}$ & $\begin{array}{c}95 \% \\
\text { CI_LB }\end{array}$ & $\begin{array}{c}95 \% \\
\text { CI_UB }\end{array}$ \\
\hline \multirow[t]{13}{*}{ FTP } & FTP1 & 0.9645 & 0.0078 & 0.9474 & 0.9757 \\
\hline & FTP2 & 0.8968 & 0.0306 & 0.8167 & 0.9402 \\
\hline & FTP3 & 0.7955 & 0.0495 & 0.6677 & 0.8653 \\
\hline & FTP4 & 0.8588 & 0.0359 & 0.7525 & 0.903 \\
\hline & FTP5 & 0.8502 & 0.0417 & 0.7453 & 0.9082 \\
\hline & FTP6 & 0.7228 & 0.055 & 0.5801 & 0.8011 \\
\hline & FTP7 & 0.8506 & 0.0382 & 0.7364 & 0.9071 \\
\hline & FTP8 & 0.8854 & 0.0341 & 0.7946 & 0.9453 \\
\hline & FTP9 & 0.8608 & 0.0482 & 0.7212 & 0.9208 \\
\hline & FTP10 & 0.7928 & 0.053 & 0.658 & 0.8807 \\
\hline & FTP11 & 0.8367 & 0.041 & 0.7475 & 0.9095 \\
\hline & FTP12 & 0.9609 & 0.0098 & 0.9337 & 0.9738 \\
\hline & FTP13 & 0.8735 & 0.0373 & 0.7868 & 0.934 \\
\hline \multirow[t]{6}{*}{ Hope } & Hope1 & 0.8165 & 0.0411 & 0.7041 & 0.878 \\
\hline & Hope2 & 0.7806 & 0.057 & 0.6465 & 0.887 \\
\hline & Hope3 & 0.9413 & 0.0136 & 0.9153 & 0.9673 \\
\hline & Hope4 & 0.8551 & 0.036 & 0.7856 & 0.9298 \\
\hline & Hope5 & 0.9022 & 0.0264 & 0.8471 & 0.9486 \\
\hline & Hope6 & 0.9077 & 0.0181 & 0.8605 & 0.9414 \\
\hline Continuance & $\mathrm{CC} 1$ & 0.7916 & 0.0546 & 0.6597 & 0.8769 \\
\hline \multirow[t]{7}{*}{ Commitment } & $\mathrm{CC} 2$ & 0.782 & 0.0521 & 0.683 & 0.8764 \\
\hline & CC3 & 0.7189 & 0.0604 & 0.5663 & 0.8058 \\
\hline & $\mathrm{CC} 4$ & 0.7976 & 0.0501 & 0.6822 & 0.8808 \\
\hline & CC5 & 0.7916 & 0.0429 & 0.689 & 0.8585 \\
\hline & CC6 & 0.732 & 0.0603 & 0.5958 & 0.8343 \\
\hline & CC7 & 0.8966 & 0.0206 & 0.8507 & 0.9312 \\
\hline & CC8 & 0.7205 & 0.0604 & 0.5514 & 0.8143 \\
\hline
\end{tabular}

Table 4. Estimates of Path Coefficient

\begin{tabular}{lcccc}
\hline \multicolumn{1}{c}{ Hypotheses } & Estimates & SE & CR & Remarks \\
\hline FTP $\rightarrow$ Continuance Commitment & 0.4138 & 0.0714 & 5.7955 & Accepted \\
FTP $\rightarrow$ Hope & 0.308 & 0.097 & 3.1753 & Accepted \\
Hope $\rightarrow$ Continuance Commitment & 0.474 & 0.0618 & 7.6699 & Accepted \\
\hline
\end{tabular}

For the hypothesis testing stage, the results of the path coefficient can be seen in Table 4 , which shows the relationship between one latent variable and another one. The calculation of the value of the critical ratio $(\mathrm{CR})$ is obtained from the estimated value divided by the standard error (SE). From the three estimated paths, the path coefficient values obtained for each path indicate that the coefficient of influence from FTP to continuance commitment is 0.4138 , FTP to hope is 0.308 , and hope to continuance commitment is 0.474. CR values which are greater than 1.96 are interpreted that the pathway has a 
significant effect between the exogenous variables on that of the endogenous, so that the entire hypothesis can be accepted.

In Table 4 above, the results show that FTP has an influence on continuance commitment. The results of this study support the findings of the research of I. J. Park \& Jung (2015) and Zacher \& Yang (2016). I. J. Park \& Jung (2015) stated that FTP can influence various work-related behaviors and attitudes, such as organizational commitments including continuance commitment. Employees will have a strong commitment to remain in the organization when the organization can provide good opportunities for them to acquire the skills, knowledge, and work experience needed to pursue their goals and future (Rudolph et al., 2018). Recruiting employees who have a strong FTP can also be a good option for the organization because it is expected that these employees will show greater commitment to their work, and their turnover intentions will be lower. It means FTP does not always appear when employees are already in the organization, but FTP has become an orientation that is firmly embedded in employees even though they have not joined the organization. A slightly different view expressed by Bal et al. (2013) which states that socioemotional fulfillment contributes to higher continuance commitment only for workers who have shallow FTP and are generally older employees, so they feel they have little opportunity to pursue their future. Therefore, they will feel that the sacrifice to be borne when leaving the organization becomes higher. Conversely, for employees who have a strong or deep FTP, continuance commitment is not something that is considered significant because they see that there are still many opportunities that remain and are possible to achieve (Zacher \& Frese, 2011), because they position themselves as an independent party to their organization.

In addition to the influence of FTP on continuance commitment, Table 4 also presents the results that FTP has a significant effect on hope. This is in line with the results of research from Ferrari et al. (2012) which support the effect of interventions based on the time perspective on increasing hope and continuity. At present, a job needs to have and to set short-term and long-term goals, ways or steps to achieve them, high strength and motives in following these goals, and solutions to deal with an obstacle. Hope is a construct that can conceptualize and operationalize the characteristics of various kinds of characteristics contained in a job (Juntunen \& Wettersten, 2006). On the other hand, someone in a different part of time is also an idea that has a proper role to direct thoughts, feelings, and behaviors. Likewise, FTP is an important construction that is able to conceptualize and operationalize attitudes (Zimbardo \& Boyd, 1999). Zimbardo \& Boyd (1999) believed that FTP is the construct that most influences hope compared to other time perspective dimensions such as past positive, past negative, and present-hedonistic. Hope is a generic concept that involves positive hope in the dimensions of work and in relations with organizations, so that hope can be a better driver of the impact of FTP's influence (Snyder et al., 2002). FTP and hope are two separate but interrelated constructs in assessing and predicting one's satisfaction because they involve a goal-based cognitive motivation process (Dwivedi \& Rastogi, 2016).

Other results presented in Table 4 are variable of hope that affects the continuance commitment. A number of studies have shown that hope has a positive effect on 
organizational commitments, including continuance commitment. Nafei (2015) in his research stated that hope positively and significantly influences continuance commitment. The more positive hope perceived by employees, the more effective the achievement of continuance commitment will be. High hope will result in more satisfaction, commitment, and high performance from members of the organization. Another group of researchers also found the fact that employees who have high hope will produce a positive commitment to the work and organization (Snyder et al., 1996, 2002). When employees feel that the organization is able to promote their hopes and happiness, they tend to give a reward in the form of a positive attitude towards the organization, including feeling of loyalty towards the organization (Nafei, 2015). Therefore, it can be concluded that hope allows employees to commit to the organization. As a result, employees who have strong hopes will stay longer in the organization because employees intrinsically feel that they belong to the organization (Kool \& Van Dierendonck, 2012). Hope involves the desire to fulfill goals, so that employees are motivated to show emotional attachment rather than merely an obligation to the organization (Fowler et al., 2017).

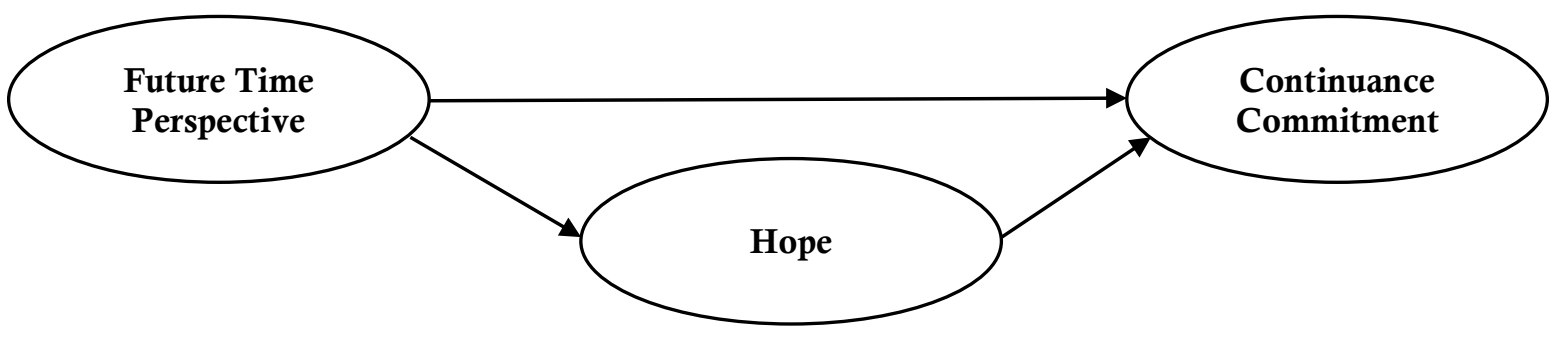

Figure 1. Hope as a mediator between FTP and continuance commitment

In this study, hope is also positioned as a mediator between FTP and continuance commitment (see Figure 1), so explicit testing is needed to determine the extent to which hope brings the influence of FTP on continuance commitment. For that reason, this study uses the Sobel test method (Sobel, 1982), the results of which can be seen in Figure 2.

\begin{tabular}{|c|c|c|c|c|}
\hline Input: & & Test statistic: & Std. Error: & $p$-value: \\
\hline a 0.308 & Sobel test: & 2.93239779 & 0.04978588 & 0.00336356 \\
\hline b 0.474 & Aroian test: & 2.91123436 & 0.0501478 & 0.00360004 \\
\hline$s_{\mathrm{a}} 0.097$ & Goodman test: & 2.95402957 & 0.04942131 & 0.00313654 \\
\hline$s_{b} 0.062$ & Reset all & & Calculate & \\
\hline
\end{tabular}

Figure 2. Calculation for the Sobel test

From the calculation of the Sobel test above, it is known the statistical test value of 2,932 (greater than 1.96) and p-value of 0.003 (less than 0.05 ), so that it can be concluded that hope is able to mediate the effect of FTP on continuance commitment. These results indicate that the influence of FTP on continuance commitment is transmitted in an important way through mental resources namely hope (Cernas-Ortiz et al., 2018). Hope has power of mediation, so that it becomes a good driver of FTP's influence on continuance commitment. 


\section{CONCLUSION}

Based on the results of data processing collected from distributing questionnaires to threestar hotel employees, it is found that FTP has a positive and significant effect on hope and continuance commitment. Likewise, hope has a positive and significant influence on continuance commitment. In this case, FTP has an important influence on continuance commitment. However, this influence is transmitted through another variable of mental resources, namely hope. Given the multi-causal nature of psychological phenomena, hope is a factor that mediates FTP and continuance commitment.

The limitation of this study is that there is only one strength of characteristics, which is hope. Therefore, it becomes too much if hope is the only (or the best) mediator of the relationship between FTP and continuance commitment. Although the calculation of mediation can be proven, hope is not enough to analyze the relationship between FTP and continuance commitment. Knowing more about other mediators of the relationship will help to better understand the effects and implications, psychological temporality on human behaviors in organizations. To better understand subjects about employee behavior in the hospitality industry, future research must analyze other factors that can mediate the relationship between FTP (and/or other time perspectives) with a variety of employee work attitudes and behaviors.

\section{REFERENCES}

Albattat, A. R., Som, A. P. M., \& Helalat, A. S. (2014). Higher Dissatisfaction Higher Turnover in the Hospitality Industry. International Journal of Academic Research in Business and Social Sciences, 4(2).

Allen, N. J., \& Meyer, J. P. (1990). The Measurement and Antecedents of Affective, Continuance and Normative Commitment to the Organization. Journal of Occupational Psychology, 63(1), 1-18.

Bal, P. M., de Lange, A. H., Zacher, H., \& Van der Heijden, B. I. J. M. (2013). A Lifespan Perspective on Psychological Contracts and Their Relations with Organizational Commitment. European Journal of Work and Organizational Psychology, 22(3), 279-292.

Bentein, K., Vandenberghe, C., Vandenberg, R., \& Stinglhamber, F. (2005). The Role of Change in the Relationship Between Commitment and Turnover: A Latent Growth Modeling Approach. Journal of Applied Psychology, 90(3), 468-482.

BPS Surabaya. (2018). Kota Surabaya Dalam Angka 2018. https://surabayakota.bps.go.id/publikasi.html

Carstensen, L. L., Isaacowitz, D. M., \& Charles, S. T. (1999). Taking Time Seriously: A Theory of Socioemotional Selectivity. American Psychologist, 54(3), 165-181.

Cernas-Ortiz, D. A., Mercado-Salgado, P., \& Davis, M. A. (2018). Future Time Perspective, Job Satisfaction, and Organizational Commitment: The Mediating Effect of Self-Efficacy, Hope, and Vitality. Revista de Psicologia Del Trabajo y de Las Organizaciones, 34(1), 1-9. 
Çetin, F. (2011). The Effects of the Organizational Psychological Capital on the Attitudes of Commitment and Satisfaction: A Public Sample in Turkey. European Journal of Social Sciences, 21(3), 373-380.

Dwivedi, A., \& Rastogi, R. (2016). Future Time Perspective, Hope and Life Satisfaction: A Study on Emerging Adulthood. Jindal Journal of Business Research, 5(1), 17-25.

Epel, E. S., Bandura, A., \& Zimbardo, P. G. (1999). Escaping Homelessness: The Influences of Self-Efficacy and Time Perspective on Coping with Homelessness. Journal of Applied Social Psychology, 29(3), 575-596.

Ferrari, L., Nota, L., \& Soresi, S. (2012). Evaluation of an Intervention to Foster Time Perspective and Career Decidedness in a Group of Italian Adolescents. Career Development Quarterly, 60(1), 82-96.

Fowler, D. R., Weber, E. N., Klappa, S. P., \& Miller, S. A. (2017). Replicating Future Orientation: Investigating the Constructs of Hope and Optimism and Their Subscales Through Replication and Expansion. Personality and Individual Differences, 116, 22-28.

Fruiht, V. M. (2014). Beyond Wills and Ways: Expanding the Scope of Snyder's Hope Model to Understand the Transmission of Hope Through Fevelopmental Relationships. In ProQuest Dissertations and Theses. http://ezproxy.lib.ryerson.ca/login?url=https://search.proquest.com/docview/1645 770215?accountid=13631\%0Ahttp://sfx.scholarsportal.info/ryerson??url_ver=Z39.8 8 -

2004\&rft_val_fmt=info:ofi/fmt:kev:mtx:dissertation\&genre=dissertations $+\% 26+$ thes es\&sid=ProQ:ProQ.

Guillon, O., \& Cezanne, C. (2014). Employee Loyalty and Organizational Performance: A Critical Survey. Journal of Organizational Change Management, 27(5), 839-850.

Hofmann, V., \& Stokburger-Sauer, N. E. (2017). The Impact of Emotional Labor on Employees' Work-life Balance Perception and Commitment: A Study in the Hospitality Industry. International Journal of Hospitality Management, 65, 47-58.

Holston-Okae, B. L., \& Mushi, R. J. (2018). Employee Turnover in the Hospitality Industry Using Herzberg's Two-Factor Motivation-Hygiene Theory. International Journal of Academic Research in Business and Social Sciences, 8(1).

Hwang, H., Takane, Y., \& Jung, K. (2017). Generalized Structured Component Analysis with Uniqueness Terms for Accommodating Measurement Error. Frontiers in Psychology, 8(DEC).

Juntunen, C. L., \& Wettersten, K. B. (2006). Work Hope: Development and Initial Validation of a Measure. Journal of Counseling Psychology, 53(1), 94-106.

Ko, J. W., Price, J. L., \& Mueller, C. W. (1997). Assessment of Meyer and Allen's ThreeComponent Model of Organizational Commitment in South Korea. Journal of Applied Psychology, 82(6), 961-973. 
Kool, M., \& Van Dierendonck, D. (2012). Servant Leadership and Commitment to Change, the Mediating Role of Justice and Optimism. Journal of Organizational Change Management, 25(3), 422-433.

Ludema, J. D., Wilmot, T. B., \& Srivastva, S. (1997). Organizational Hope: Reaffirming the Constructive Task of Social and Organizational Inquiry. Human Relations, 50(8), 1015-1051.

Luthans, F. (2002). Positive Organizational Behavior: Developing and Managing Psychological Strengths. Academy of Management Executive, 16(1), 57-72.

Luthans, F., Avey, J. B., \& Patera, J. L. (2008). Experimental Analysis of a Web-Based Training Intervention to Develop Positive Psychological Capital. Academy of Management Learning and Education, 7(2), 209-221.

McGee, G. W., \& Ford, R. C. (1987). Two (or More?) Dimensions of Organizational Commitment: Reexamination of the Affective and Continuance Commitment Scales. Journal of Applied Psychology, 72(4), 638-641.

Meyer, J. P., \& Allen, N. J. (1984). Testing the "Side-Bet Theory" of Organizational Commitment: Some Methodological Considerations. Journal of Applied Psychology, 69(3), 372-378.

Meyer, J. P., \& Allen, N. J. (1991). A Three-Component Conceptualization of Organizational Commitment. Human Resource Management Review, 1(1), 61-89.

Meyer, J. P., Stanley, D. J., Herscovitch, L., \& Topolnytsky, L. (2002). Affective, Continuance, and Normative Commitment to the Organization: A Meta-Analysis of Antecedents, Correlates, and Consequences. Journal of Vocational Behavior, 61(1), 20 52 .

Nafei, W. (2015). The Effects of Psychological Capital on Employee Attitudes and Employee Performance: A Study on Teaching Hospitals in Egypt. International Journal of Business and Management, 10(3).

Park, I. J., \& Jung, H. (2015). Relationships Among Future Time Perspective, Career and Organizational Commitment, Occupational Self-Efficacy, and Turnover Intention. Social Behavior and Personality, 43(9), 1547-1562.

Park, N., Peterson, C., \& Seligman, M. E. P. (2004). Strengths of Character and Well-Being. Journal of Social and Clinical Psychology, 23(5), 603-619.

Qiu, H., Haobin Ye, B., Hung, K., \& York, Q. Y. (2015). Exploring Antecedents of Employee Turnover Intention - Evidence of China's Hotel Industry. Journal of China Tourism Research, 11(1), 53-66.

Quinn, R. E., \& Thakor, A. V. (2018). Creating A Purpose-Driven Organization. Harvard Business Review, July-August.

Reid, E., \& Ramarajan, L. (2016). Managing the High-Intensity Workplace. Harvard Business Review, June, 84-90. 
Rudolph, C. W., Kooij, D. T. A. M., Rauvola, R. S., \& Zacher, H. (2018). Occupational Future Time Perspective: A Meta-Analysis of Antecedents and Outcomes. Journal of Organizational Behavior, 39(2), 229-248.

Snyder, C. R., Rand, K. L., King, E. A., Feldman, D. B., \& Woodward, J. T. (2002). "False" Hope. Journal of Clinical Psychology, 58(9), 1003-1022.

Snyder, C. R., Sympson, S. C., Ybasco, F. C., Borders, T. F., Babyak, M. A., \& Higgins, R. L. (1996). Development and Validation of the State Hope Scale. Journal of Personality and Social Psychology, 70(2), 321-335.

Sobel, M. E. (1982). Asymptotic Confidence Intervals for Indirect Effects in Structural Equation Models. Sociological Methodology, 13, 290.

Stinglhamber, F., Bentein, K., \& Vandenberghe, C. (2002). Extension of the ThreeComponent Model of Commitment to Five Foci: Development of Measures and Substantive Test. European Journal of Psychological Assessment, 18(2), 123-138.

Tamer, I., \& Dereli, B. (2014). The Relationship Between Interpersonal Trust, Peer Support and Organizational Commitment. Öneri Dergisi, 11(42), 175.

Tomic, I., Tesic, Z., Kuzmanovic, B., \& Tomic, M. (2018). An Empirical Study of Employee Loyalty, Service Quality, Cost Reduction and Company Performance. Economic Research-Ekonomska Istrazivanja, 31(1), 827-846.

Zacher, H., \& Frese, M. (2011). Maintaining a Focus on Opportunities at Work: The Interplay Between Age, Job Complexity, and the Use of Selection, Optimization, and Compensation Strategies. Journal of Organizational Behavior, 32(2), 291-318.

Zacher, H., \& Yang, J. (2016). Organizational Climate for Successful Aging. Frontiers in Psychology, 7(JUL).

Zimbardo, P. G., \& Boyd, J. N. (1999). Putting Time in Perspective: A Valid, Reliable Individual-Differences Metric. Journal of Personality and Social Psychology, 77(6), 12711288.

Zimmerman, R. D., Swider, B. W., \& Boswell, W. R. (2019). Synthesizing Content Models of Employee Turnover. Human Resource Management, 58(1), 99-114. 